\title{
The use of a risk-orientated approach in comprehensive assessment of natural and technogenic emergency situations in the Kashirsky Municipal District of the Voronezh Region, Russia
}

\author{
Tatyana V. Ovchinnikova, Nikolay D. Razinkov, Pavel S. Kuprienko, \\ Tatyana V. Ashikhmina, Anastasia V. Shmygol, Anastasia A. Pavlenko \\ Voronezh State Technical University, Voronezh, Russia
}

\section{Principal contact}

Tatyana V. Ovchinnikova, Candidate of Biological Sciences, Associate Professor, Department of Technosphere Safety and Fire Safety, Voronezh State Technical University; 84, 20-letiya Oktyabrya St, Voronezh, Russia 394006.

Tel. +79204669695

Email tvo0104@mail.ru

ORCID https://orcid.org/0000-0002-7780-1231

How to cite this article

Ovchinnikova T.V., Razinkov N.D., Kuprienko P.S., Ashikhmina T.V., Shmygol A.V., Pavlenko A.A. The use of a risk-orientated approach in comprehensive assessment of natural and technogenic emergency situations in the Kashirsky Municipal District of the Voronezh Region, Russia. South of Russia: ecology, development. 2021, vol. 16, no. 3, pp. 127-141.

DOI: 10.18470/1992-1098-2021-3-127-141

Received 14 August 2020

Revised 21 December 2020

Accepted 26 April 2021

\begin{abstract}
The article reviews methodological approaches to risk assessment based on a comprehensive analysis of the frequency of natural and technological hazards in the territory of the Kashirsky Municipal District of the Voronezh Region.

Aim. The purpose of this article is to assess and calculate the risks of emergency situations, based on a comprehensive analysis of the frequency of occurrence of natural and technological hazards in the Kashirsky Municipal District of the Voronezh Region, Russia.

Methods. The risk assessment methods employed were based on the combined characteristics of damage and frequency of occurrence of negative environmental or man-caused processes or hazardous events. Events associated with certain losses or people impacted upon by dangers were considered as negative processes.

Results. The Kashirsky Municipal District is exposed to high risks of flooding, wildfires, biological and social processes, hazards associated with certain housing and communal service regimes and transportation accidents. There are also hydraulic structures and potentially hazardous facilities which increase risks of property damage in the area.

Conclusion. It is necessary to reduce the level of social risk by carrying out preventive activities aimed at minimizing casualties. All scheduled maintenance requirements should be complied with in order to prevent a rise of risk of accident in life sustaining systems and infrastructures. The development of governmental departmental emergency monitoring systems, quarantine procedures and timely observational measures are recommended with the objective of reducing potential biological and social emergencies.
\end{abstract}

Key Words

Risk, measures, flood, construction, system, warning, erosion, accident, quarantine.

(C) 2021 The authors. South of Russia: ecology, development. This is an open access article under the terms of the Creative Commons Attribution License, which permits use, distribution and reproduction in any medium, provided the original work is properly cited. 


\title{
Использование риск-ориентированного подхода \\ в комплексной оценке природных и техногенных чрезвычайных ситуаций на территории Каширского муниципального района Воронежской области
}

\author{
Татьяна В. Овчинникова, Николай Д. Разиньков, Павел С. Куприенко, \\ Татьяна В. Ашихмина, Анастасия В. Шмыголь, Анастасия А. Павленко \\ Воронежский государственный технический университет, Воронеж, Россия
}

\section{Контактное лицо}

Татьяна В. Овчинникова, кандидат

биологических наук, доцент, кафедра техносферной и пожарной безопасности, Воронежский государственный технический университет; 394006 Россия, г. Воронеж, ул. 20летия Октября, 84.

Тел. +79204669695

Email tvo0104@mail.ru ORCID https://orcid.org/0000-0002-7780-1231

Формат цитирования

Овчинникова Т.В., Разиньков Н.Д., Куприенко П.С., Ашихмина Т.В., Шмыголь А.В., Павленко А.А. Использование риск-ориентированного подхода в комплексной оценке природных и техногенных чрезвычайных ситуацийна территории Каширского муниципального района Воронежской области // Юг России: экология, развитие. 2021. T.16, N 3. С. 127-141. DOI: 10.18470/1992-1098-2021-3-127-141

Получена 14 августа 2020 г.

Прошла рецензирование 21 декабря 2020 г. Принята 26 апреля 2021 г.

\begin{abstract}
Резюме
В статье рассматриваются методологические подходы оценки рисков, которые основаны на комплексном анализе частоты развития природных и техногенных опасностей на территории Каширского муниципального района Воронежской области.

Цель. Дать оценку и рассчитать риски чрезвычайных ситуаций (ЧС), которые основаны на комплексном анализе частоты развития природных и техногенных опасностей на территории Каширского муниципального района Воронежской области.

Методы. В основу методов оценки природного и техногенного риска положена комбинированная характеристика ущерба и частоты негативного природного или техногенного процесса или события. В качестве негативных процессов рассматриваются события, связанные с определёнными потерями (отказами) или реципиентами опасности. Результаты. Территория Каширского района подвержена рискам, связанным с половодьем, природными пожарами, биологосоциальными процессами, в системах ЖКХ и транспорте. На территории района имеются гидротехнические сооружения и потенциально опасные объекты с повышенными рисками материальных ущербов.

Заключение. Для снижения уровня социального риска необходимо проводить превентивные мероприятия, направленные на уменьшение потерь. С целью недопущения роста риска аварий на системах жизнеобеспечения следует проводить все виды планового ремонта. С целью уменьшения биолого-социальных ЧС рекомендуется развивать ведомственные системы мониторинга ЧС, своевременно вводить карантинные и обсервационные мероприятия.

Ключевые слова

Риск, мероприятие, половодье, сооружение, система, оповещение, эрозия, авария, карантин.
\end{abstract}

(C) 2021 Авторы. Юг России: экология, развитие. Это статья открытого доступа в соответствии с условиями Сreative Commons Attribution License, которая разрешает использование, распространение и воспроизведение на любом носителе при условии правильного цитирования оригинальной работы. 


\section{INTRODUCTION}

The major hazards in the Kashirsky Municipal District of the Voronezh Region are:

1. Natural: exogenous - gully formation and upland erosion; hydrospheric - spring flooding; weather extremes (strong winds, downpours, hailstorms, snowdrifts, frosts and dry spells with associated wildfires).

2. Technological: anthropogenic - hydrodynamic accidents in waterwork systems; accidents in housing and communal services facilities (water supply network, electric power and heating systems); accidents at hazardous industrial facilities and traffic accidents (road and rail).

3. Biological and social: epidemics, epizootics and epiphytotics.

\section{MATERIAL AND METHODS}

The Kashirsky Municipal Distict of the Voronezh Region was the object of this research. Its located in the Oka-Don Lowland with a total area is $1,060.20 \mathrm{sq} . \mathrm{km}$. It is distinguished by incised river valleys and a less pronounced dissection of the ravine-beam network relative to other areas of the region in the Russian Plain and Kalach Upland. The district's hydrographic network is represented mainly by the Don and Hvorostan Rivers. Relief does not exceed $170 \mathrm{~m}$ above sea level. Suffusion depressions are often found, with the largest forms being more than $100 \mathrm{~m}$ with depths of $1.5 \div 2 \mathrm{~m}$.

The district has a mostly temperate continental climate. Maximum annual relative humidity is $80-85 \%$. Average annual rainfall is $571 \mathrm{~mm}$. Westerly winds are dominant $(22 \%)$ throughout the year but southerly wind changes are also very typical (14\%) [1].

Surface and underground waters are characterized by low water availability, the district occupying an intermediate position according to the volume of water resources in the region per head of population. Local surface water runoff resources are more than 50 thousand $\mathrm{m}^{3}$ per $\mathrm{km}$, while the operational resources of fresh groundwater are 70-90 thousand $\mathrm{m}^{3} /$ day.

The Kashirsky District has floodplain meadows and forests in the basins of the Don and Hvorostan Rivers. In its western part there are pine and broad-leaved-pine forests which pose a threat of large wildfires during forest fire seasons [2;3].

A comprehensive assessment of environmental and technogenic emergencies investigated in the district included: statistics of emergency accidents at objects of the same type as has occurred in the past; a graphoanalytical study of the causal relationships of factors leading to accidents; expert assessments of hazardous environmental and technogenic processes; results of express analysis of observed parameters of functioning objects; "hazard indices" (specially designed hazard scales for potentially hazardous substances and relevant quantities) and risk assessments of regional and federal governmental departments, in particular emergency situations of a biological and social nature.

Operational forecasting methods of Russian EMERCOM were used in predicting the parameters of damaging impacts and their territorial distribution.

Approved methods and scientific work carried out under the supervision of the Russian Academy of Sciences, Russian EMERCOM and the Russian Scientific Society for Risk Analysis were used to determine different types of damages [4].
Industrial facilities zoning and facilities separation based on acceptable risk criteria was carried out using methodological approaches developed by the Russian Scientific Society for Risk Analysis and normative documents of the Russian Ministry of Emergency Situations $[1 ; 5]$. The acceptable level for risk of emergencies in the Voronezh Region is considered to be $5.72 \cdot 10^{-6} 1$ /year [6]. The maximum allowable value of social risk in terms of the "victim" indicator was adopted as $10^{-4}$ cases per year in relation to an expected less than 10 number of victims [7].

Natural and man-made risk assessment methods for the Kashirsky District were based on the combined characteristics of the damage and the frequency of negative natural or man-caused processes or accidents. Only those events that are associated with certain losses (failures) of the hazard recipient were considered in negative key.

In order to assess environmental risks, the physical risk of damage in the territory was assessed. It should be noted that this group of risk is crucial for calculating other types of risk, in particular the economic risk of land reduction as a result of exogenous processes. This is expressed by a function [8]:

$$
\operatorname{Re}(\mathrm{H})=\operatorname{Rf}(\mathrm{H}) \mathrm{d}_{\mathrm{e}},(1)
$$

where $-\operatorname{Rf}(\mathrm{H})$ is the physical risk of land loss ( $\mathrm{m} /$ year, ha/year, $\mathrm{km}^{2} /$ year and etc.);

$d_{e}$ is the distribution of material value (cost of material distribution) (rub./ $\mathrm{m}^{2}$, rub./ha, rub./ $\mathrm{km}^{2}$ and etc.).

In order to found a new indicator of the social risk, $d_{e}$ can be replaced with population density $d_{p}$ (inhabitants per square $\mathrm{km}$ or inhabitants per hectare) in the formula above:

$$
R_{p}(H)=R_{f}(H) d_{p},(2)
$$

This type of risk determines the ability of processes (one or more) to be in the zone of catastrophic development during a certain period of time and, accordingly, economic, material and physical losses, including fatal consequences.

In cases when social and other types of risk are mapped from hazardous natural and technogenic processes which are isolated in the field of fixing losses, their specific indicators which directly characterise the possible damage are used. Accordingly, the individual risk of affecting the population with a certain result, which determines the probability of being an injured member of the risk group in the zone of possible damage, is a specific indicator and criterion for ranking the territory. This type of risk is expressed as the formula below:

$$
R_{j}(H)=R_{f}(H) d_{p} P(I)=d_{p}(H) P(I),(3)
$$

where $d_{p}$ is the population density (inhabitants per square $\mathrm{km}$ or inhabitants per hectare);

$P(I)=1 / m$ means the probability that one in the risk zone will be injured (unit fraction);

$m$ is the size of the group (members); $R_{s}(H)$ is the total social risk of injured population (member/year).

More detailed information about risk assessment in different backgrounds is connected with an additional account of the vulnerability of individual objects of the economy, population and biocenoses which are under the influence of dangerous natural and technogenic processes of a certain intensity and phenomena, destructive power and duration of exposure.

The mathematical risk models considered are used to assess elementary negative effects from dangers of certain genesis, intensity (destructive force) and duration 
of effect on homogeneous objects (territories, structures, population groups, etc.). The sum of the elementary danger events for all possible cases of risks, which differ in frequency of occurrence, intensity or rate of development and negative consequences, expresses the full differentiated (private) risk from this danger as inside one as inside all objects in the affected area. The sum of the differentiated risks from all genetic types of hazards affecting an object (s) determines the integral (total) risk of direct losses in the physical, economic, social or environmental spheres of their occurrence.

\section{RESULTS AND DISCUSSION}

Risk assessment of environmental emergency

The risk of exogenous processes. The Kashirsky Municipal District is subject to ravine erosion and medium-intensity karst development (Fig. 1). The results of monitoring studies in this regard were produced by TC Voronezhgeomonitoring AO Centralnoe PGO.

According to actual data obtained about the types of exogenous process, by analogy and extrapolation with known values, data obtained (with an allowable error of $\pm 0.5 \%)$ is shown below in Table 1 .

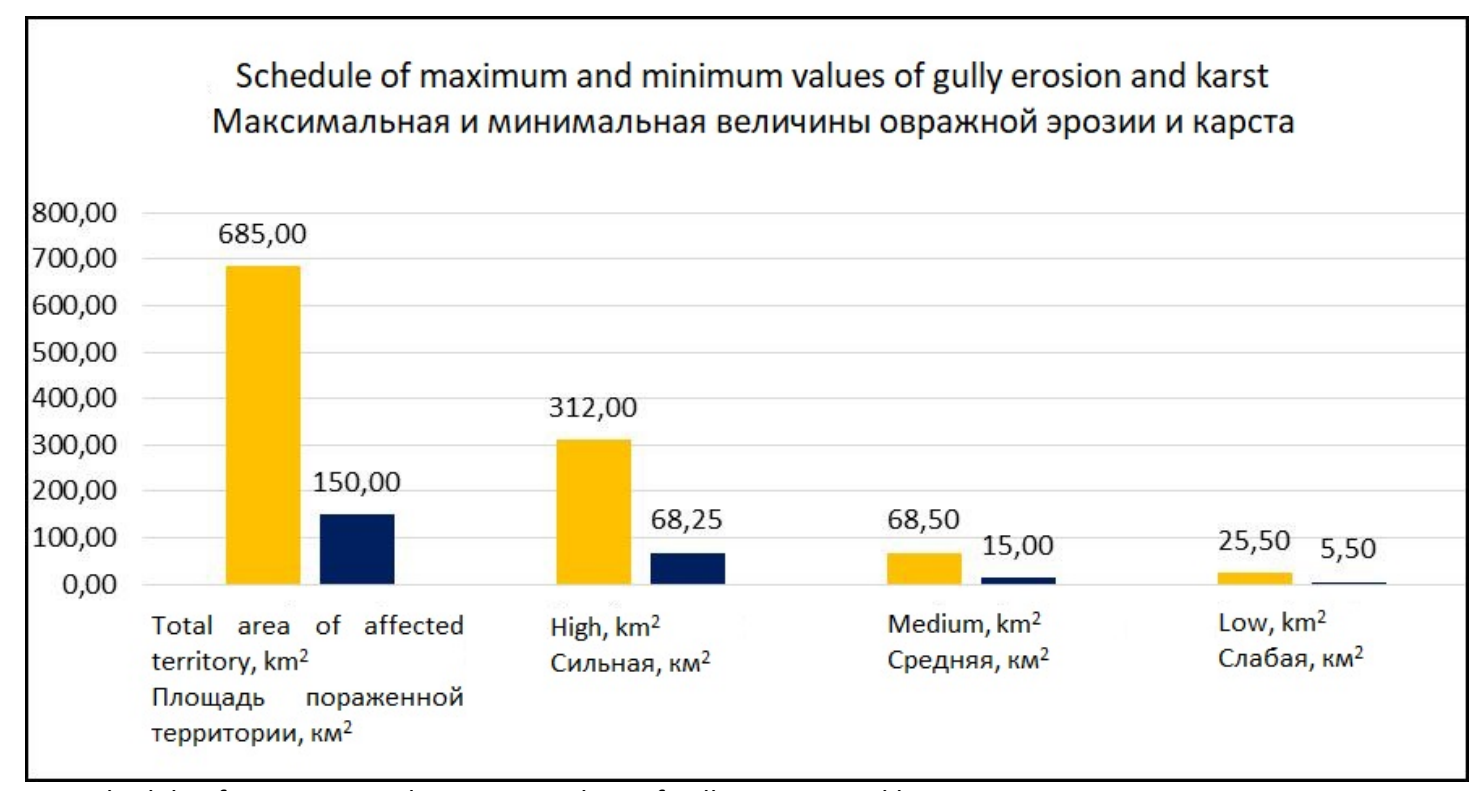

Figure 1. Schedule of maximum and minimum values of gully erosion and karst

Рисунок 1. График максимальной и минимальной величины овражной эрозии и карста

Table 1. The Exogenous Processes of the Kashirsky Municipal District

Таблица 1. Экзогенные процессы Каширского муниципального района

\begin{tabular}{|c|c|c|c|c|}
\hline \multirow{2}{*}{$\begin{array}{l}\text { Form of exogenous } \\
\text { processes } \\
\text { Вид экзогенного } \\
\text { процесса }\end{array}$} & \multirow{2}{*}{$\begin{array}{c}\text { Total area } \\
\text { of affected territory, } \mathbf{k m}^{2} \\
\text { Площадь пораженной } \\
\text { территории, км² }\end{array}$} & \multicolumn{3}{|c|}{$\begin{array}{l}\text { Range of influence on the territory } \\
\text { Степень пораженности территории }\end{array}$} \\
\hline & & $\begin{array}{c}\text { High, } \mathbf{k m}^{2}(\%) \\
\text { Сильная, км² (\%) }\end{array}$ & $\begin{array}{l}\text { Medium, } \mathbf{k m}^{2}(\%) \\
\text { Средняя, км² (\%) }\end{array}$ & $\begin{array}{l}\text { Low, } \mathbf{k m}^{2}(\%) \\
\text { Слабая, км² (\%) }\end{array}$ \\
\hline $\begin{array}{l}\text { Gully erosion } \\
\text { Овражная эрозия }\end{array}$ & 685 & $312(45,5 \%)$ & $68,5(10 \%)$ & $25,5(3,7 \%)$ \\
\hline $\begin{array}{l}\text { Karst } \\
\text { Kарст }\end{array}$ & 150 & $68,25(45,5 \%)$ & $15(10 \%)$ & $5,5(3,7 \%)$ \\
\hline
\end{tabular}

a) The methodology developed in "Assessment and Management of Natural Risks" [8] and SNiP 22-01-95 "Geophysics of Hazard Natural Processes" were used to assess the risk of gully erosion. In accordance with this $\mathrm{SNiP}$, the range of gully erosion was assessed as low (100 $\mathrm{m}^{2} / \mathrm{km}^{2}$ ). Therefore, the actual risk of loss of the territory as a result of erosion will be:

$R_{\mathrm{fj}}(C)=R_{\mathrm{fs}}(C) S_{\mathrm{j}}=100 \cdot 312=31200 \mathrm{~m}^{2} / \mathrm{km}^{2}\left(3,1 \cdot 10^{-2} \mathrm{~m}^{2} / \mathrm{km}^{2}\right)$

Accordingly, full ravine erosion and specific economic risks of losses in the district will be:

$R_{c}(C)=R_{f j}(C) d_{c}=3,1 \cdot 10^{-2} \cdot 1 \cdot 1,12=34$ thousand rub/year; $R_{c s}(C)=R_{e}(C) / S_{j}=34 / 312=109 \mathrm{rub} / \mathrm{km}^{2}$ year

b) Karst risk is calculated using the above cited methodology [8]. The area intensity of karst deformations for the middle category of karst hazard is $R_{\mathrm{fs}}(C)=0,016$ $\mathrm{m}^{2} / \mathrm{km}^{2}$ year and the density of the natural-technical system is equal to 1.12 million $\mathrm{rub} / \mathrm{km}^{2}$.

The karst risk of loss of territory is: $R_{\mathrm{fj}}(C)=R_{f_{s}}(C) \cdot S_{j}=0,016 \cdot 15=0,24 \mathrm{~m}^{2} / \mathrm{km}^{2}$ year.
The final values of the social and individual karst risks for the population of the Kashirsky Municipal District are defined as a medium range risk.

c) Flood risk. A number of settlements in the Kashirsky District periodically fall into the flood zone (Table 2).

The amount of compensation payments was taken according to real payments for the year 2018 based on possible flooding ranges (expert assessment).

In order to assess social and material damages for appropriate flood protection, the method of aggregate indicators was applied [8]. It is considered advisable to use this method in the absence of detailed data about the situation in areas affected by accidents and sufficient data in geographic information systems. In accordance with this method, the average statistical data of object characteristics and the population density of the territory under consideration are used. 
Table 2. Number of Flooded Buildings

Таблица 2. Количество затапливаемых домов

\begin{tabular}{|c|c|c|c|c|c|c|c|}
\hline \multirow[t]{2}{*}{ No } & \multirow[t]{2}{*}{$\begin{array}{c}\text { Location } \\
\text { Населенный пункт }\end{array}$} & \multirow[t]{2}{*}{$\begin{array}{l}\text { Bodies of water } \\
\text { Водные объекты }\end{array}$} & \multicolumn{5}{|c|}{$\begin{array}{l}\text { The number of buildings flooded } \\
\text { at the highestwater level P \% } \\
\text { Іество домов, затапливаемых наивысшим } \\
\text { ем воды с вероятностью превышения Р\% }\end{array}$} \\
\hline & & & 1 & 5 & 10 & 25 & 50 \\
\hline 1. & $\begin{array}{l}\text { Biryuchenskoye } \\
\text { Бирюченское }\end{array}$ & $\begin{array}{l}\text { Hvorostan } \\
\text { Хворостань }\end{array}$ & 19 & 16 & 11 & 2 & 0 \\
\hline 2. & $\begin{array}{c}\text { Mosalskoe } \\
\text { Мосальское }\end{array}$ & $\begin{array}{l}\text { Hvorostan } \\
\text { Хворостань }\end{array}$ & 47 & 41 & 8 & 0 & 0 \\
\hline $\begin{array}{l}\text { Total } \\
\text { Bcero }\end{array}$ & & & 66 & 57 & 19 & 2 & 0 \\
\hline $\begin{array}{l}\text { Comp } \\
\text { Компє }\end{array}$ & $\begin{array}{l}\text { tion payments, millic } \\
\text { ционные выплаты, }\end{array}$ & $\begin{array}{l}\text { ubles } \\
\text { pyб. }\end{array}$ & 1,76 & 1,52 & 0,52 & 0,04 & 0 \\
\hline
\end{tabular}

Assessment of social and material damages were carried out in accordance with local regulatory requirements [6].

As a result of plans established for each area, the locations of Buryachenko (11 buildings), Mosalskoe (9 buildings) were found as points inside the zone with average flood impact.

d) Calculation of risks associated with weather extremes such as strong winds, heavy rain, hail, snow drifts, frosts and droughts are based on a statistical method. The statistical information was taken from the existing database of the territorial centre for monitoring and forecasting emergencies. Social and individual risks for this type of emergency were not considered. Frequencies of accidents that turn into emergencies are taken from available statistics for the past 10 years.

Over the past 10 years, the recorded number of emergencies of these types of environmental events was 18. The number of registered municipalities in the region is 34 (31 municipal regions and 3 urban districts).

Thus, the frequency of the types of noted emergencies: $F_{\text {wind. }} ; F_{\text {rainfall. }} F_{\text {hailstorm; }} F_{S D} ; F_{\text {frost }} ; F_{\text {d., }}$ where $F_{\text {wind. }}$ is $1,8 \cdot 1 / 34=1,8 \cdot 2,94 \cdot 10^{-2}=5,3 \cdot 10^{-2} 1$ /year. If the emergency level for the district is considered as municipal, therefore, economic damage for assessing financial risk is taken as the equivalent of 500 minimum wages [9], which means 5.640 million rubles for the year 2019. The amount of financial risk is calculated as:

$\mathrm{R}_{\mathrm{G}}=1,8 \cdot 2,94 \cdot 10^{-2} \cdot 5,640=0,3$ million rub./year.

e) Risk assessment of wild fires. Statistical data from the existing database of the territorial centre for monitoring and forecasting emergencies was utilised in calculating risk associated with forest fires. The frequency of wildfires is determined based on statistics of the last 10 years. The social and individual risks for this type of emergency were not considered.

To assess this type of emergency risk, it is incorrect to employ overall statistics for the region, because forest cover of municipal districts varies significantly and significant differences are also observed in forest structure. There are some fragments of pine and broad-leaved forest in the western part of the region. A forest fire has been recorded once (local scale) in the last 10 years.

Thus, the frequency of this type of emergency of the municipal area is $F_{\text {forest }}=110^{-1} 1 /$ year. The emergency level for the area was considered as local, therefore, economic damage to assess financial risk is taken to be the equivalent of 500 minimum wages. The amount of financial risk is:

$$
R_{G}=1 \cdot 10^{-1} \cdot 5,640=0,564 \text { million rub./year. }
$$

\section{Risk assessment of man-made emergencies}

a) Hydro-technical installations accident risks.

There are two potentially dangerous waterworks in the Kashirsky Municipal District:

1) The Moskovsky Pond (reservoir) in the Kondrashkin Log Ravine, $0.5 \mathrm{~km}$ to the east of the $\mathrm{M}-4$ road. The hydro-technical installation is federal property of the Federal State Budget Institution, Voronezhmeliovodkhoz. In 2018, the structure was repaired and the waterworks are in a satisfactory condition.

Should dam destruction occur, the M-4 federal road is located along the hydrodynamic flow path. Thus the roadway could be damaged on the reservoir side, requiring repair work (Fig. 2);

2) The Mosalsky Pond (reservoir) in the municipal ownership of the Kashirsky District administration (although it is located closer to Mosalkoye which is at a distance of $0.75 \mathrm{~km}$ to the northeast).

The Mosalskoye settlement is located inside a zone of potential danger; 9 houses of Nine Yanvarya Street could be damaged by the influence of a potential breakout wave (the first level, in the destruction zone, 3 buildings and on the second, in the flooding zone, 6 buildings. Currently, the hydro-technical installation requires repair (Fig. 3).

To determine the hydrodynamic accident indicators of this hydro-technical installation, programme modules Volna OOO NPP Titan-Optima were used, the results being shown in Tables 3 and 4.

The frequency of emergencies in Table 3 are taken on the basis that the hydraulic facility state is in a balance and, based on the assigned service life of the established relevant class, accident frequency assessment corresponds to an acceptable level of risk for a hydraulic facility of class IV.

b) Risk of accidents at hazardous industrial facilities in the Kashirsky Municipal District.

There are two potentially dangerous facilities in the Kashirsky Municipal District located at Kolodezniy:

1) Solvent-extraction plant manufacturer - Branch of OOO BUNGE SNG (Safety Data Sheet dated 2015);

2) Prom-Neft-Service Petroleum Products Company

(Safety Data Sheet dated 2013) [10]. 


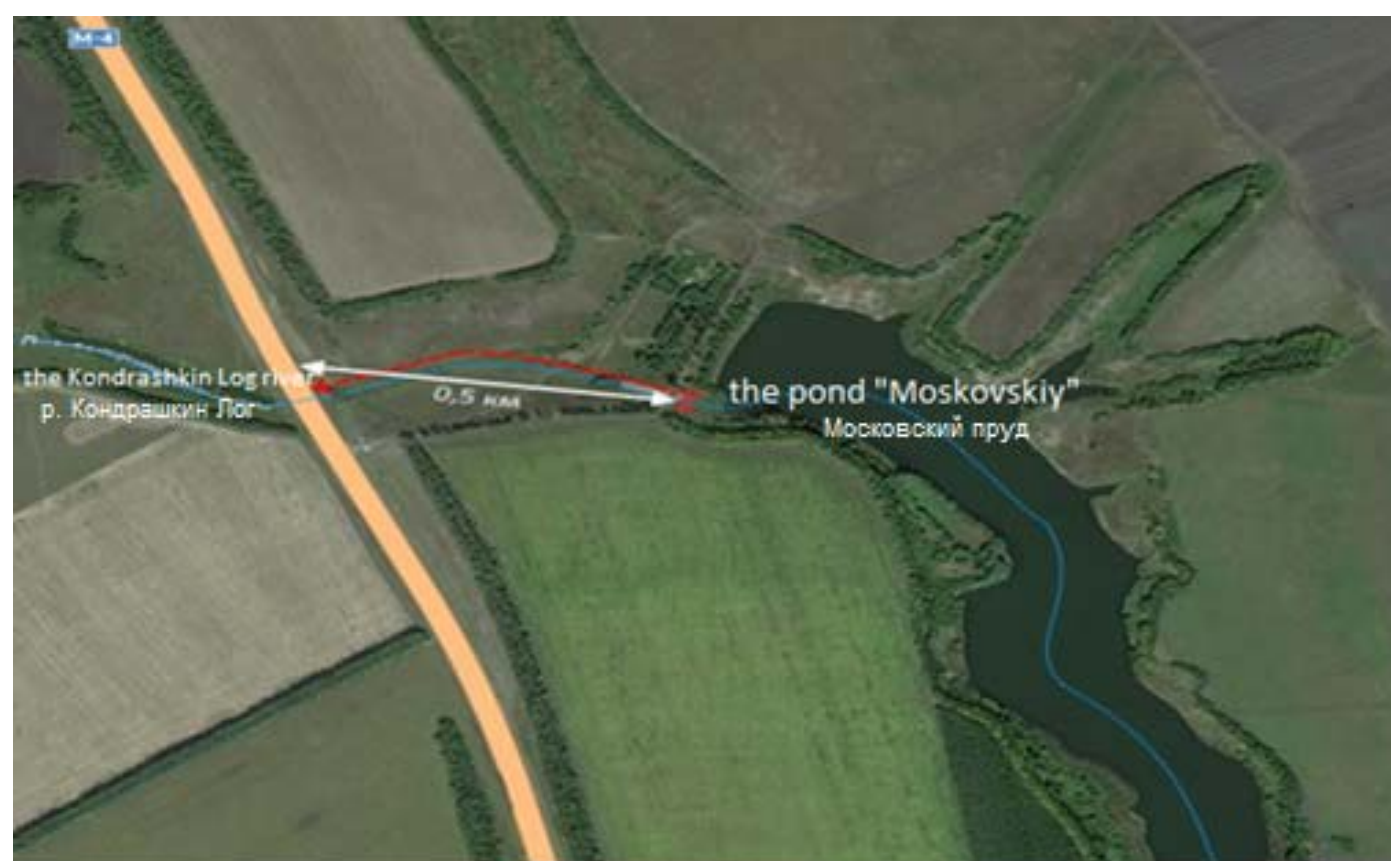

Figure 2. Locational plan of the M-4 road, $0.5 \mathrm{~km}$ from the Moskovsky Pond (M 1: 10 000)

Рисунок 2. Ситуационный план трассы М-4 на 0,5 км от пруда «Московский» (М 1: 10 000)

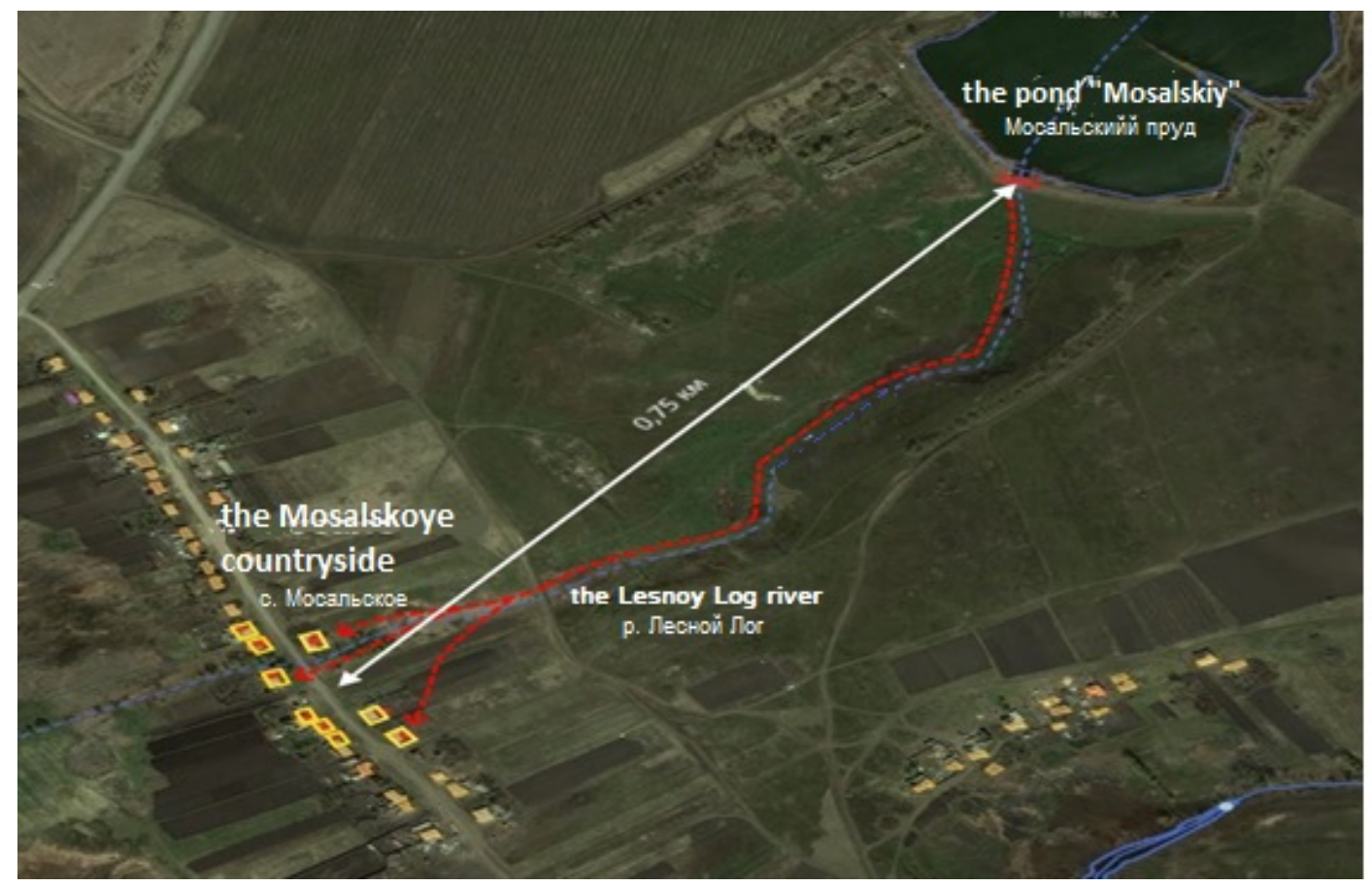

Figure 3. Locational plan of the Mosalskoye settlement, $0.75 \mathrm{~km}$ from the Mosalskiy Pond (M 1: 10000 )

Рисунок 3. Ситуационный план с. Мосальское на 0,75 км от пруда «Мосальский» (М 1: 10 000)

The main indicators characterizing the safety of these industrial installations are summarised in Table 4 (Fig. 4).

c) Risk of emergency at housing and public utilities.

Emergencies related to housing and communal services are considered as a daily possibility of violating the living conditions of the population of the Kashirsky Municipal District.

Calculations of the emergency risk assessment of housing and utilities services are based on statistical methodology. Statistics were taken from the database of the territorial centre for monitoring and forecasting emergency situations and the Department of Housing, Utilities Services and Energy of the Voronezh Region. Data about frequency of accidents has been determined from statistics of the last 10 years. Social and individual risks for these types of accidents have not been considered.

1. The frequency of emergency situations of the electric power system of the Kashirsky Municipal District is $F_{E P S}=2 \cdot 10^{-1} 1 /$ year. The emergency level is classed as of the municipal type. Economic damage for assessing financial risk is taken to be the equivalent of 500 minimum wages. The amount of financial risk is calculated as:

$$
\mathrm{R}_{\mathrm{G}}=2 \cdot 10^{-1} \cdot 5,640=1,128 \cdot 10 \text { million rub./year. }
$$

2. There has been no emergency in the water supply systems during the last ten years. 
Table 3. Accidents at hydraulic structures

Таблица 3. Риск ЧС на ГТС

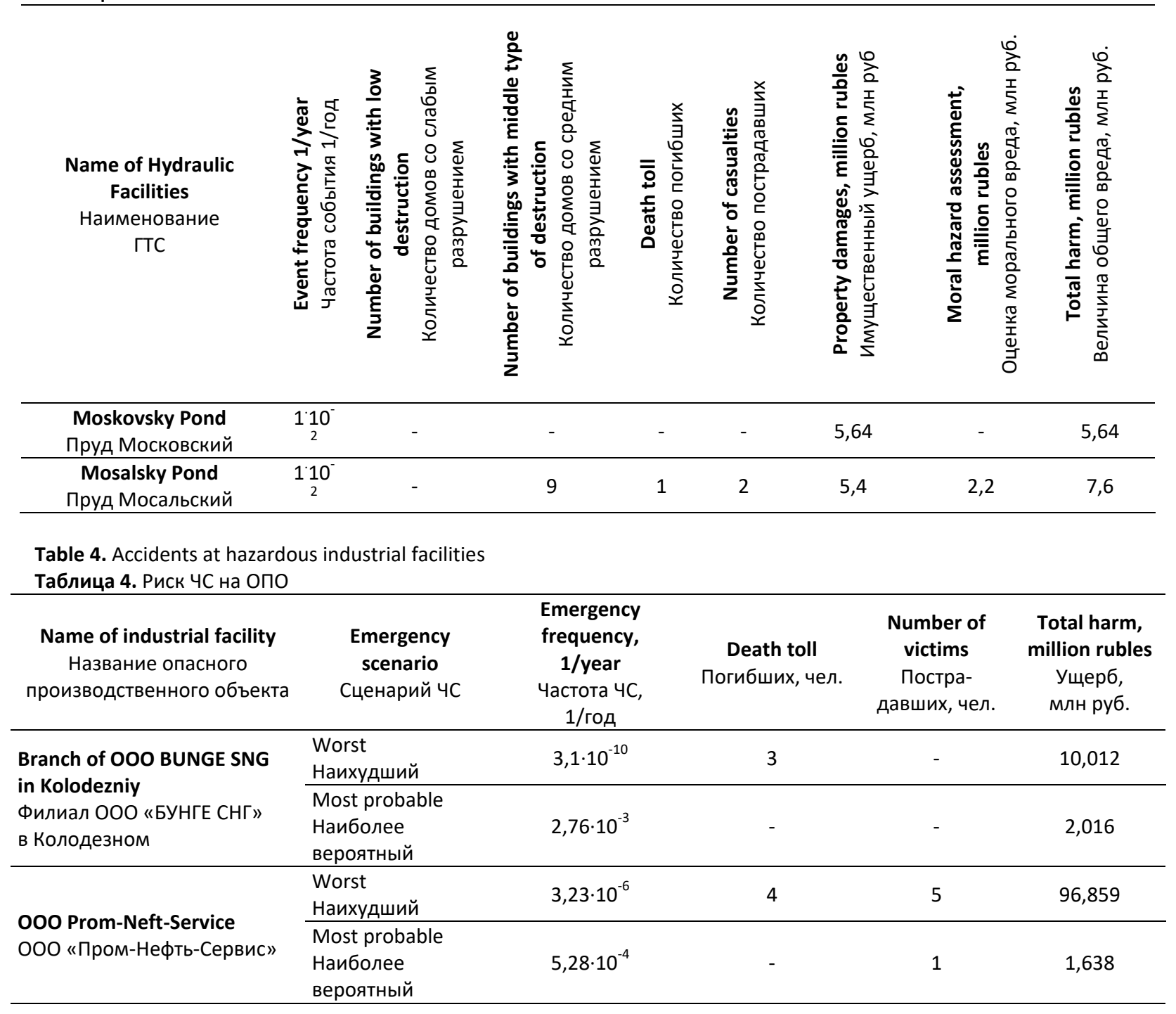

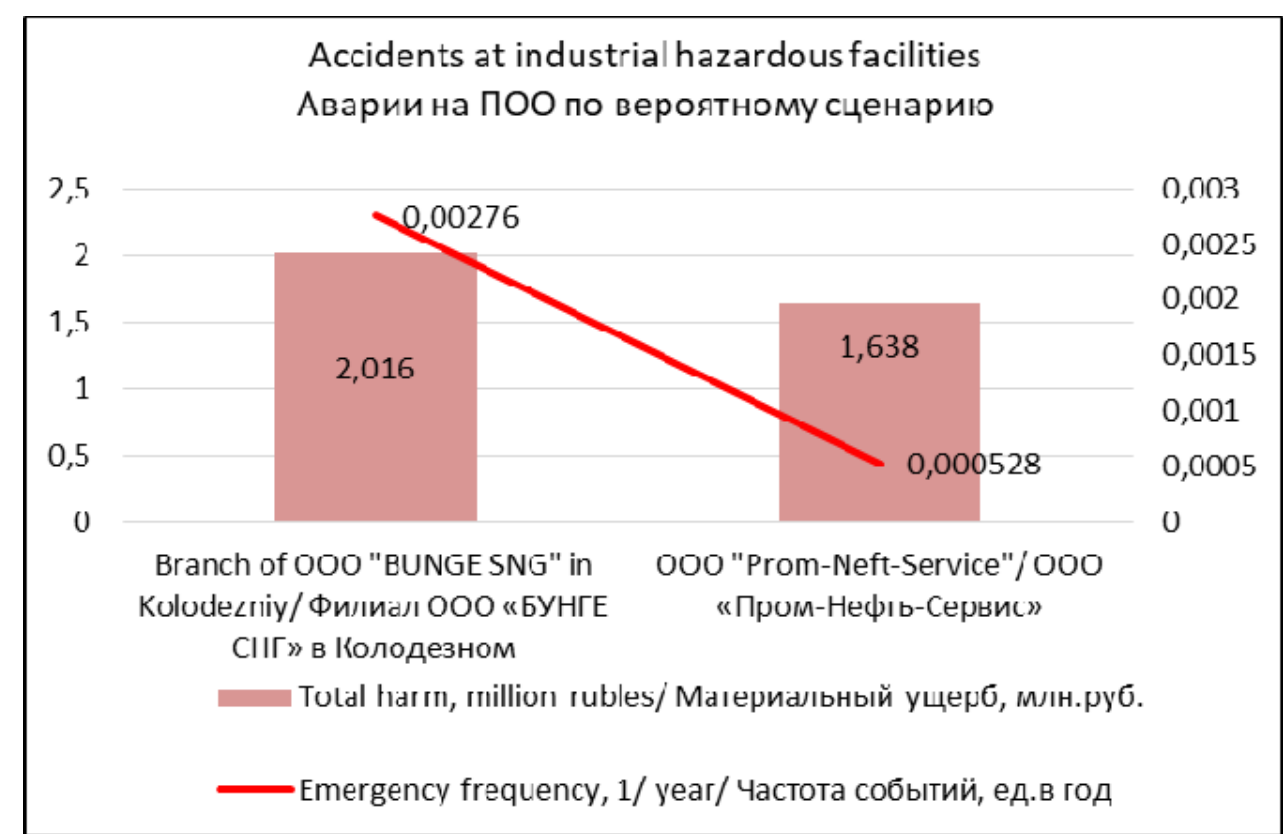

Figure 4. Risk indicators for accidents at industrial hazardous facilities in the Kashirsky Municipal District according to the most probable scenario

Рисунок 4. Аварии на ПОО в Каширском муниципальном районе по вероятному сценарию 
3. Regional statistics of heating systems of the Voronezh Region as a whole have been used because there is no statistical data for the Kashirsky Municipal District as an entity. Boiler rooms with their heating system are taken as an object (housing and communal services) to be studied (there are 2,088 in the Voronezh Region). Nevertheless, according to the statistical data regarding incidents involving heating equipment in the Kashirsky Municipal District, there were 11 emergencies.

Thus, the frequency of the study object emergency, including the heating system of the region is calculated as being:

$$
F_{\text {heat }}=1,1 \cdot 1 / 2088=5,3 \cdot 10^{-4} 1 / \text { year (Fig. 5). }
$$

According to the information available, there are 58 such objects in the region. Therefore, the total risk indicator will be:

$$
F_{\text {heat }}=5,3 \cdot 10^{-4} \cdot 58=3,1 \cdot 10^{-2} 1 / \text { year. }
$$

Economic damage in the assessment of financial risk is taken as the equivalent of 500 minimum wages, because the emergency level is classed as of a municipal type. The amount of financial risk is:

$$
R_{G}=3,1 \cdot 10^{-2} \cdot 5,640=1,75 \cdot 10^{-1} \text { million rub./year. }
$$

d) Risk of transport accidents (Fig. 6).

1. Road traffic accident risk assessment. The result was obtained with reference to the statistical data of the traffic police of the Kashirsky Municipal District. The frequency of emergency is $F_{\text {road }}=2 \cdot 10^{-1} 1 /$ year. The emergency level is local and of municipal type. The economic damage for assessing financial risk is taken as the equivalent of 500 minimum wages. The amount of financial risk is:

$F_{\text {road }}=2 \cdot 10^{-1} \cdot 5,640=1,128 \cdot 10^{0}$ million rub./year.
If the average annual number of deaths from road traffic accidents is 8 people (over the past 10 years), then the individual risk of an accident will be:

$$
R_{\text {roadt }}=8 / 23802=3.36 \cdot 10^{-4} 1 / \text { year. }
$$

2. Railway accident risk assessment. There is no information about emergency statistics relating to railroad accidents in the Kashirsky District during the past 10 years. Thus, calculations were based on regional statistics of the number of emergencies of the Voronezh Region over the past 10 years: i.e. 1 territorial emergency, 4 local and 4 community emergencies. Municipalities in the region with railways number 28 . Accordingly, frequencies of railway transport incidents in the municipal area are calculated as:

- for the worst type of scenario

$F_{\text {railway }}=1 \cdot 10^{-1} \cdot 1 / 28=3,6 \cdot 10^{-2} 1 /$ year;

- for the most probably type of scenario

$F_{\text {railway }}=8 \cdot 10^{-1} \cdot 1 / 28=2,9 \cdot 10^{-1} 1$ /year.

The worst type of emergency is at the regional level, while the most probably type of scenario is at the municipal level. Therefore, the economic damage through financial risk assessment is taken to be in the amount of 247,5 million-ruble as an average criterion for a regional type of emergency [11] and the equivalent of 500 minimum wages is taken as the most probably type of scenario (Fig. 7). Accordingly, the amount of financial risk is:

- for the worst type of scenario

$R_{G}=3,6 \cdot 10^{-2} \cdot 247,5=8,91 \cdot 10$ million rub./year;

- for the most probably type of scenario

$\mathrm{R}_{\mathrm{G}}=2,9 \cdot 10^{-1} \cdot 5,640=1,64 \cdot 10^{0}$ million rub./year.

Social and individual risks of railway accidents were not calculated due to the lack of statistics.

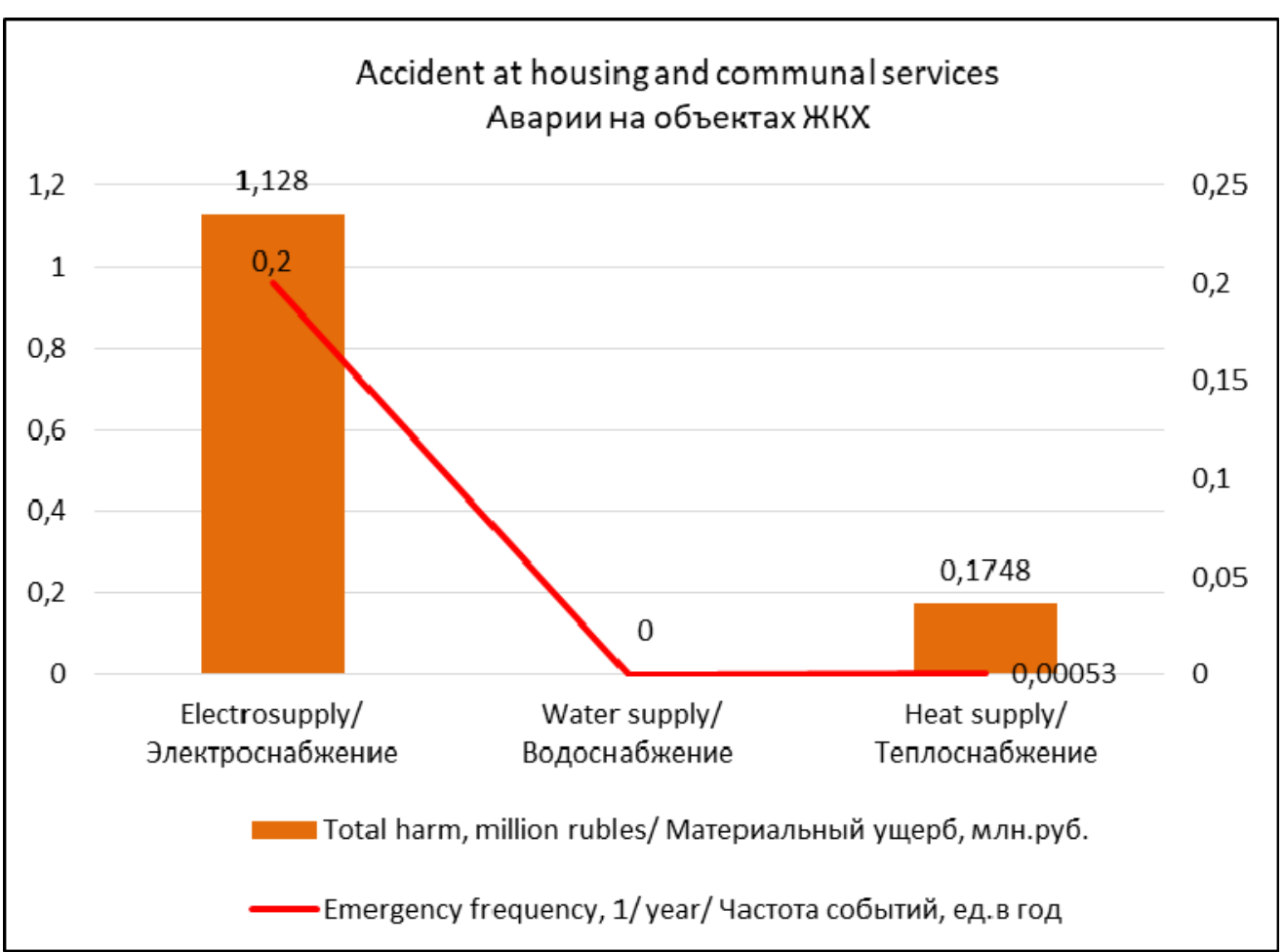

Figure 5. Dependence graph of financial damage of an accident occurring with housing and communal services Рисунок 5. График зависимости финансового ущерба при наступлении аварии на объектах ЖКХ 


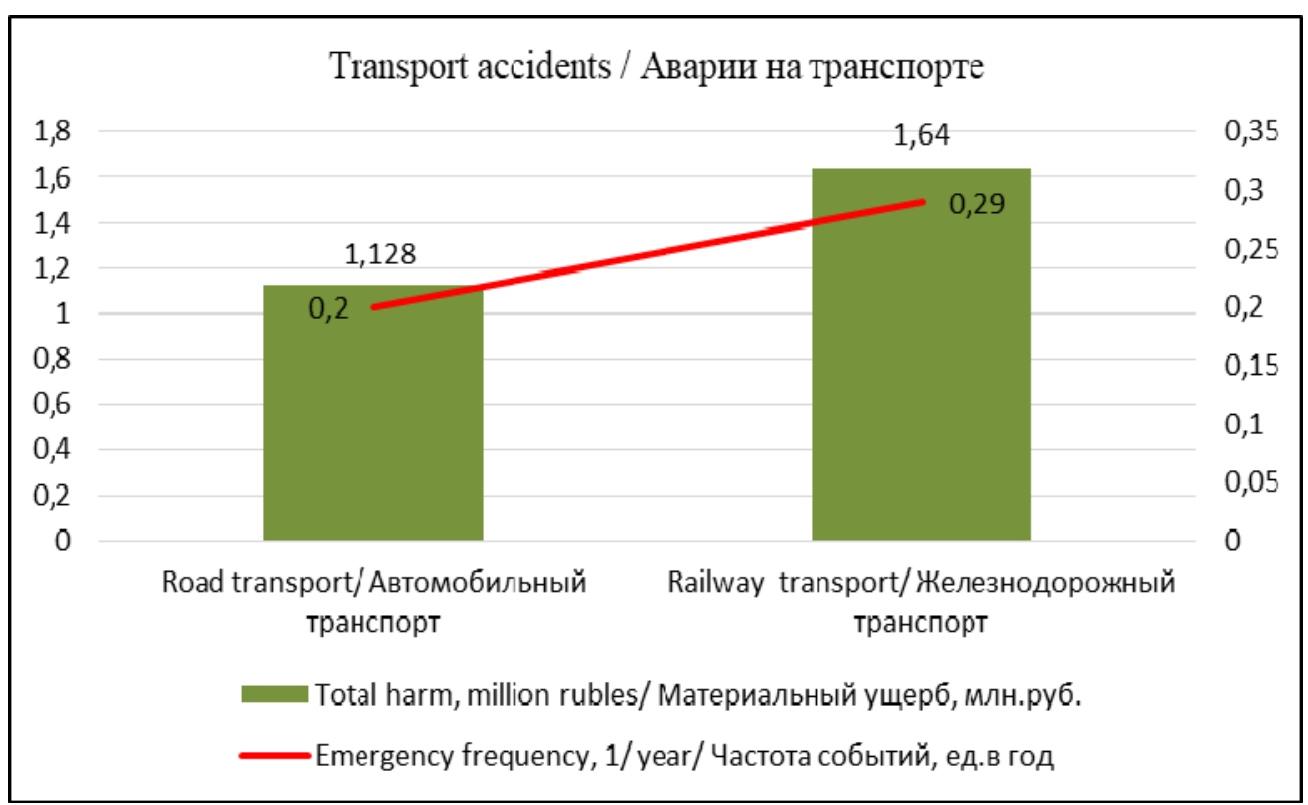

Figure 6. Graph of financial damage of an accident according to different modes of transport

Рисунок 6. График зависимости финансового ущерба при наступлении аварии

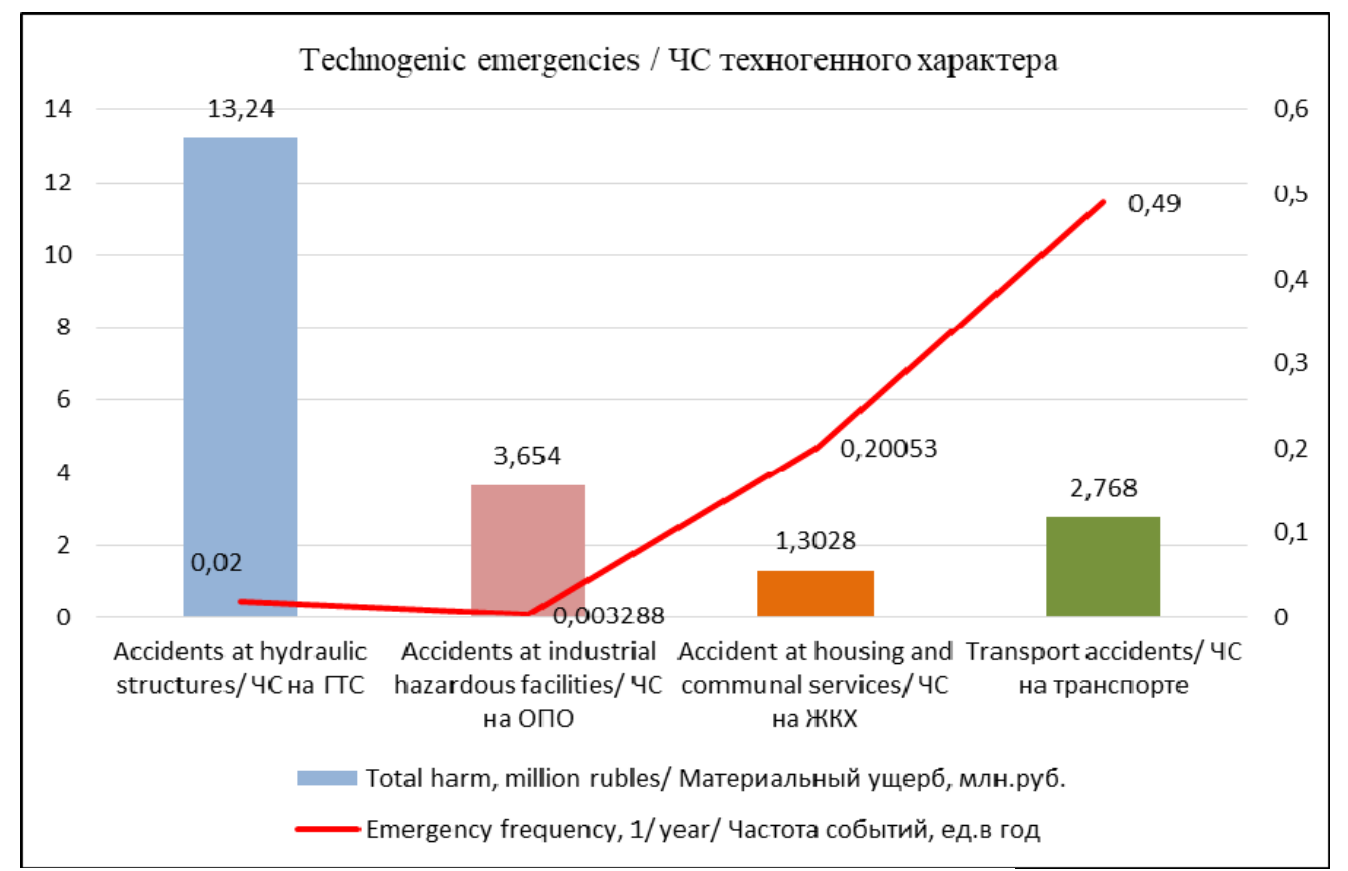

Figure 7. General assessment of the risk of material damage to technogenic emergencies

Рисунок 7. Общая оценка риска материального ущерба техногенных ЧС

Risk assessment of socio-biological emergencies

a) Risk of epidemics. Regional statistics were used to assess the risk of emergencies in the territory of the Kashirsky Municipal District, because there were no emergencies with an extremely high index of the incidence or mortality rate in this area (i.e. exceeding the average annual by more than 3) [11].

The municipal level of emergency epidemic situations has been registered once in the Voronezh Region over a 10 year period. Based on the information that the Kashirsky Municipal consists of 32 territories, the frequency of this type of emergency is calculated as:

$$
F_{\text {social. }}=1 \cdot 10^{-1} \cdot 1 / 32=3,1 \cdot 10^{-3} 1 / \text { year. }
$$

The economic damage for assessing financial risk is taken as the equivalent of 500 minimum wages, because the type of emergency on the area is considered as municipal.
In this case, the amount of financial risk is: $\mathrm{R}_{\text {social. }}=3,1 \cdot 10^{-3} \cdot 5,640=1,75 \cdot 10^{-2}$ million rub./year.

b) Risk of epizootics. There are no cattle farms and pig farms in the Kashirsky Municipal District. Consequently, statistics of the animal incidence of the Voronezh Region as a whole were used to assess the risk of emergencies in the Kashirsky Municipal District.

Emergency situations of epizootics have been registered once on a municipal level in the Voronezh Region (32 municipal districts) for the last ten years. Thus, the frequency of this type of emergency (taking into account the absence of pig farms in the municipal district) is calculated as:

$$
F_{\text {animals. }}=1 \cdot 10^{-1} \cdot 1 / 32=3,1 \cdot 10^{-3} 1 / \text { year. }
$$

The emergency level of epizootics in the Kashirsky District is classed as of municipal type. The economic damage for assessing financial risk is taken as the 
equivalent of 500 minimum wages.

The amount of financial risk is calculated as:

$\mathrm{R}_{\mathrm{G}}=3,1 \cdot 10^{-3} \cdot 5,640=1,75 \cdot 10^{-2}$ million rub./year.

c) Risk of epiphytotics. The prevailing hazardous pests and diseases of crops and forests are considered in the territory of the Kashirsky Municipal District:

Pests affecting crops:

- Rodents - these occur annually during the springsummer or autumn-winter periods when there are favorable weather conditions in most of the area.

- Locusts - a local population which has no economic value.

- Moths - 1-2 times during the season over a period of 6-12 years. Pest outbreaks with increased density may occur if weather conditions have been favourable in May-June for two consecutive years (i.e. $\mathrm{T}=20-25^{\circ} \mathrm{C}$ and humidity of more than $75 \%$ ). It is possible that moths migrate from adjacent territories that provide natural habitat foci.

- Bugs - approximately every 10 years, individual foci occur with high numbers. If weather conditions are favourable in the spring-summer period with the earth to $20^{\circ} \mathrm{C}$, the insect begins to move in active searching pf winter cereal crops.

- Colorado beetle - outbreaks occur every year, insecticide treatments being used against the larvae of the pest's first generation, while treatment of $30-50 \%$ of the entire sown area of potato is required against larvae of the second generation [12].

2. Crop diseases:

- Septoria leaf spot - occurs every two years when there is a combination of favourable weather conditions (wet) a month before crops starting to sprout;
- Brown leaf rust - occurs every two to three years, its progression being based on a relatively warm winter, rainfall in the first half of the growing season and cool, humid weather in August and September. Treatments are carried out when the disease occurs, during tillering and exit into the tube.

Regional statistics were used to assess the risk of crops succumbing to diseases and pests in the territory of the Kashirsky Municipal District.

The territorial level of emergency situation has been registered once in the Voronezh Region during last 10 years. 32 municipalities in the region were taken into consideration. Thus, the recurrence of the risk of crops death from diseases and pests is calculated as:

$$
F_{c}=1^{\cdot} 10^{-1} \cdot 1 / 32=3,1 \cdot 10^{-3} 1 / \text { year. }
$$

The emergency level is classed as of the municipal type. The economic damage for assessing financial risk is taken as the equivalent of 500 minimum wages. The amount of financial risk is calculated as:

$\mathrm{R}_{\mathrm{G}}=3,1 \cdot 10^{-3} \cdot 5,640=1,75 \cdot 10^{-2}$ million rub/year;

d) Pests and diseases of the forest.

1. Forest pests: Forest cockchafer - a local population which has no economic value.

2. Forest diseases: Heterobasidion annosum extensive foci of this disease require radical control measures. It is the principal cause of drying of pines over large areas. Regional statistics of the Voronezh Region were used because there is no statistical data about the Kashirsky Municipal District specifically. Conifers constitute $24 \%$ of the total forest value of the Voronezh Region (118.5 thousand ha). Environmental reports of the territorial administration of Rosprirodnadzor indicate that radical measures for the control of Heterobasidion annosum require annual processing of about 9 thousand hectares (Fig. 8) [13].

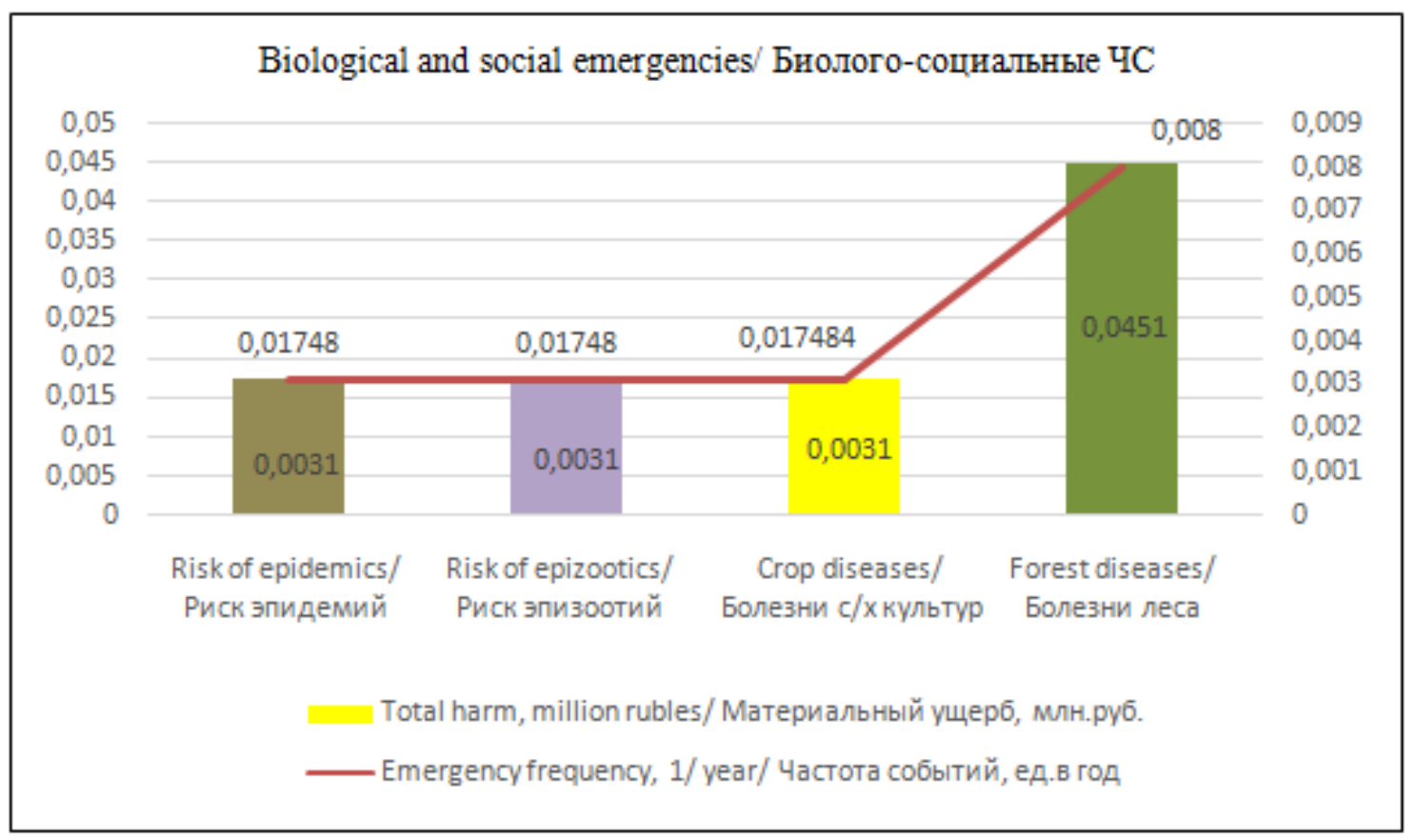

Figure 8. General assessment of the material damage risk of biological and social emergencies

Рисунок 8. Общая оценка риска материального ущерба биолого-социальных ЧС

The area of coniferous forest in the district is 3.58 thousand ha and the risk of coniferous forest disease is determined as follows:
$F_{\text {forest }}=(9 / 118,5) \cdot 3,58 \cdot 1 / 34=8,0 \cdot 10^{-3} 1 /$ year.

The emergency level is classed as of the municipal type and the economic damage for assessing financial risk 
is taken as the equivalent of 500 minimum wages. The amount of financial risk is calculated as:

$$
R_{G}=8 \cdot 10^{-3} \cdot 5,640=4,51 \cdot 10^{-2} \text { million rub/year. }
$$

Analysis of risk assessment results

The frequency of the most possible risks of emergencies in the Kashirsky Municipal District of the Voronezh Region is presented in Table 5.

Table 5. The main possible risks of an emergency on the territory of the Kashirsky municipal district of the Voronezh region Таблица 5. Основные возможные риски возникновения ЧС на территории Каширского муниципального района Воронежской области

\begin{tabular}{|c|c|c|c|c|}
\hline & 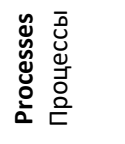 & $\begin{array}{l}\text { Risk } \\
\text { Риск }\end{array}$ & $\begin{array}{l}\text { Risk indicator - frequency } \\
\text { of accident, 1/year } \\
\text { Показатель риска - частота } \\
\text { реализации события, 1/год }\end{array}$ & $\begin{array}{l}\text { Specific of manifestations } \\
\text { Конкретные проявления }\end{array}$ \\
\hline \multicolumn{5}{|c|}{ Environmental emergency / Природные ЧС } \\
\hline \multirow{2}{*}{\multicolumn{2}{|c|}{ 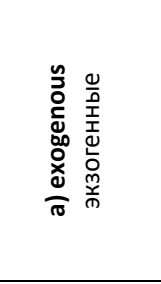 }} & $\begin{array}{l}\text { Gully erosion } \\
\text { Овражная эрозия }\end{array}$ & 0.06 & $\begin{array}{l}\text { Occupies } 64.6 \% \text { within the territory of the } \\
\text { municipal area } \\
\text { Занимает } 64,6 \% \text { в пределах территории } \\
\text { муниципального района }\end{array}$ \\
\hline & & $\begin{array}{l}\text { Karst } \\
\text { Суффозионные процессы } \\
\text { (карсты) }\end{array}$ & 0.02 & $\begin{array}{l}\text { Occupies 0,10\% within the territory of the } \\
\text { municipal area } \\
\text { Занимает 0,10\% в пределах территории } \\
\text { муниципального района }\end{array}$ \\
\hline \multirow{2}{*}{\multicolumn{2}{|c|}{ 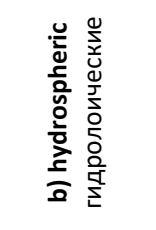 }} & \multirow{2}{*}{$\begin{array}{l}\text { Spring flood on the river } \\
\text { Hvorostan } \\
\text { Весеннее половодье на р. } \\
\text { Хворостань }\end{array}$} & 0.04 & $\begin{array}{l}\text { Floods the settlement Biryuchenskoye } \\
\text { Подвержен затоплению населённый пункт } \\
\text { Бирюченское }\end{array}$ \\
\hline & & & 0.03 & $\begin{array}{l}\text { Floods the settlement Mosalskoe } \\
\text { Подвержен затоплению населённый пункт } \\
\text { Мосальское }\end{array}$ \\
\hline \multirow{6}{*}{\multicolumn{2}{|c|}{ 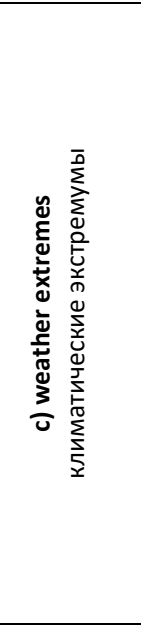 }} & $\begin{array}{l}\text { Strong wind } \\
\text { Сильный ветер }\end{array}$ & 0.04 & $\begin{array}{l}\text { Within the territory of the municipal area } \\
\text { В пределах территории муниципального } \\
\text { района }\end{array}$ \\
\hline & & $\begin{array}{l}\text { Rainfall } \\
\text { Ливни }\end{array}$ & 0.04 & $\begin{array}{l}\text { Within the territory of the municipal area } \\
\text { В пределах территории муниципального } \\
\text { района }\end{array}$ \\
\hline & & $\begin{array}{l}\text { Hail } \\
\text { Град }\end{array}$ & 0.03 & $\begin{array}{l}\text { Within the territory of the municipal area } \\
\text { В пределах территории муниципального } \\
\text { района }\end{array}$ \\
\hline & & $\begin{array}{l}\text { Snow drifts } \\
\text { Снежные заносы }\end{array}$ & 0.03 & $\begin{array}{l}\text { Within the territory of the municipal area } \\
\text { В пределах территории муниципального } \\
\text { района }\end{array}$ \\
\hline & & $\begin{array}{l}\text { Frost } \\
\text { Замороски }\end{array}$ & 0.04 & $\begin{array}{l}\text { Within the territory of the municipal area } \\
\text { В пределах территории муниципального } \\
\text { района }\end{array}$ \\
\hline & & $\begin{array}{l}\text { Drought } \\
\text { Засуха }\end{array}$ & 0.03 & $\begin{array}{l}\text { Within the territory of the municipal area } \\
\text { В пределах территории муниципального } \\
\text { района }\end{array}$ \\
\hline \multicolumn{2}{|r|}{ 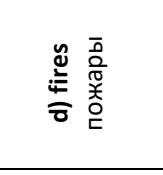 } & $\begin{array}{l}\text { Forest } \\
\text { Лесные }\end{array}$ & 0.04 & $\begin{array}{l}\text { Areas of pine and broad-leaved forests are } \\
\text { located in the Western part of the region } \\
\text { В западной части района расположены } \\
\text { фрагменты соснового и широколиственного } \\
\text { леса }\end{array}$ \\
\hline \multicolumn{5}{|c|}{ Technogenic emergencies / Техногенные ЧС } \\
\hline \multirow{4}{*}{ 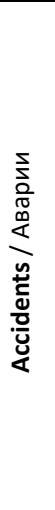 } & \multirow{2}{*}{ 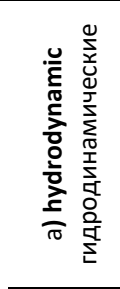 } & $\begin{array}{l}\text { Hydrotechnical facilities closer to } \\
\text { the Kondrashkin Log ravine } \\
\text { ГТС в балке Кондрашкин Лог }\end{array}$ & 0.06 & $\begin{array}{l}\text { The pond "Moskovskiy" is placed } 0.5 \\
\text { kilometers to the east of the M-4 route } \\
\text { Восточнее от трассы M-4 на 0,5 км - } \\
\text { расположен пруд «Московский» }\end{array}$ \\
\hline & & $\begin{array}{l}\text { Hydrotechnical facilities near the } \\
\text { Mosalskoye countryside } \\
\text { ГТС у с. Мосалькое }\end{array}$ & 0.04 & $\begin{array}{l}\text { The pond "Mosalskiy" is placed at a distance of } \\
0.75 \mathrm{~km} \text { to the Northeast } \\
\text { На удалении 0,75 км на северо-восток - } \\
\text { расположен пруд «Мосальский» }\end{array}$ \\
\hline & \multirow{2}{*}{ 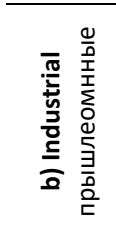 } & $\begin{array}{l}\text { Branch of OOO "BUNGE SNG" in } \\
\text { Kolodezniy } \\
\text { Филиал ООО «БУНГЕ СНГ» } \\
\text { в Колодезном }\end{array}$ & 0.04 & $\begin{array}{l}\text { The territory of Kolodezniy } \\
\text { п. Колодезный }\end{array}$ \\
\hline & & $\begin{array}{l}\text { O०О "Prom-Neft-Service" } \\
\text { ООО «Пром-Нефть-Сервис» }\end{array}$ & 0.06 & $\begin{array}{l}\text { The territory of Kolodezniy } \\
\text { п. Колодезный }\end{array}$ \\
\hline
\end{tabular}




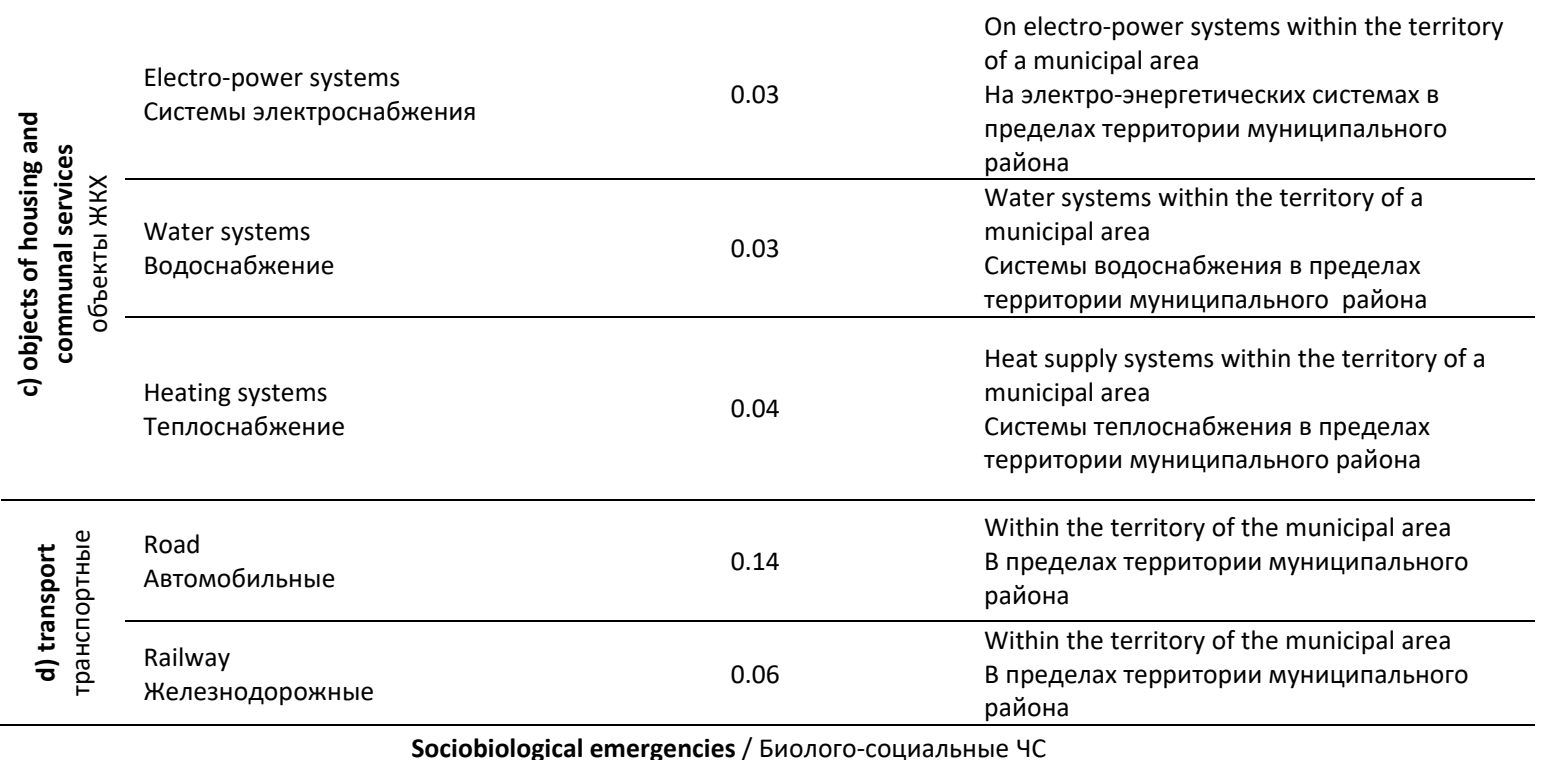

\begin{tabular}{cll}
\hline \multicolumn{1}{c}{ Sociobiological emergencies / Биолого-социальные чС } \\
\hline
\end{tabular}

The principal output of the risk assessment for the territory of the Kashirsky Municipal District of the Voronezh Region was the construction of the following diagrams of social risk and risks of damage to property (F / N-F / G-diagrams) (Figs. 9 \& 10).
An analysis of Fig. 9 defines the social risk for the area as slightly higher than the maximum allowable. This is based, first of all, on the presence of 11 zones of inundation from flooding and from 2 ponds (reservoirs) which pose a direct threat to population.

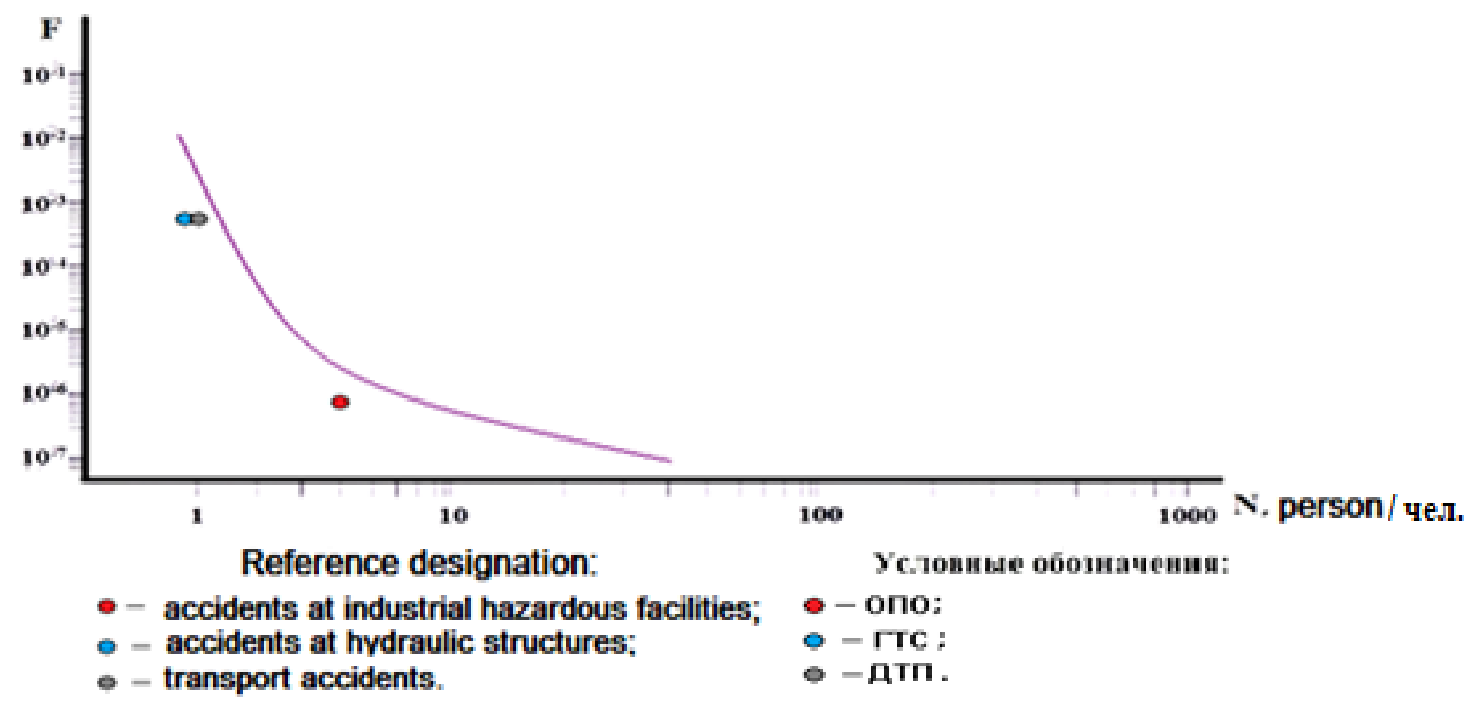

Figure 9. Social risk

Рисунок 9. Социальный риск 


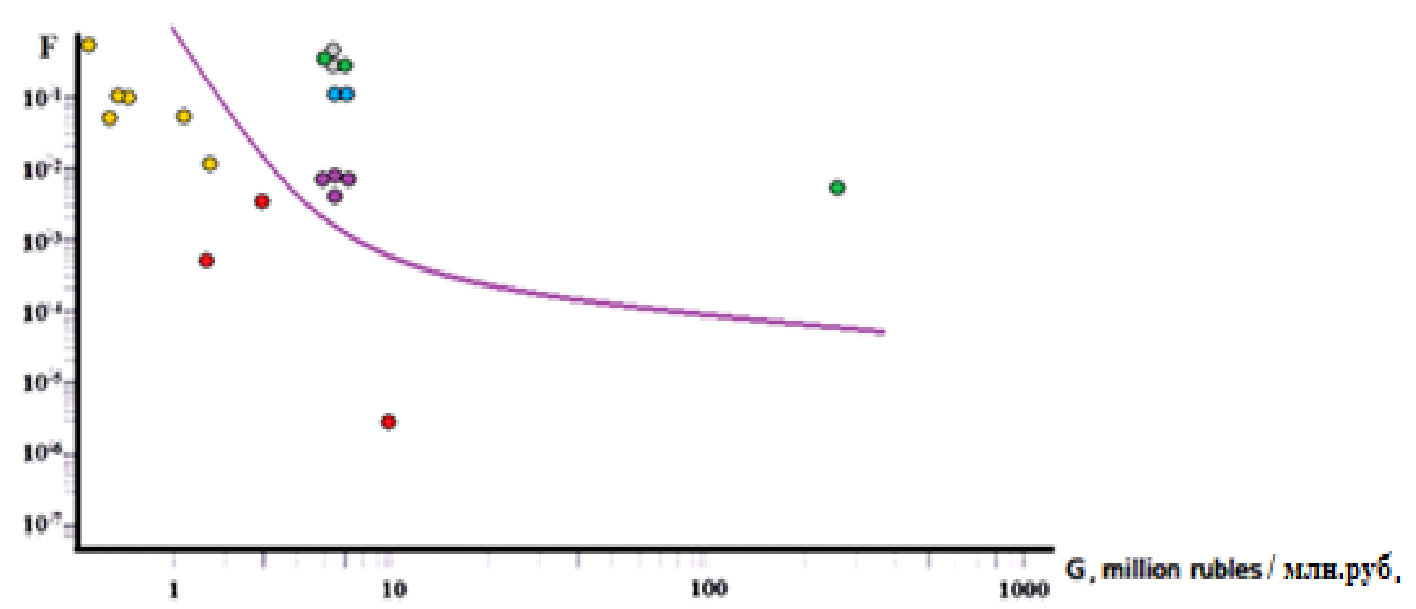

Reference designation:

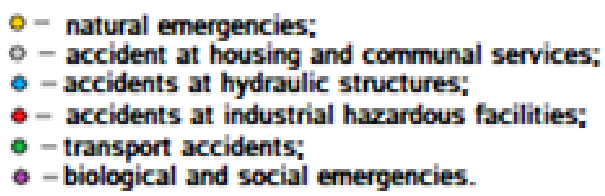

Figure 10. Risks of damage to property

Рисунок 10. Риск материального ущерба

Based on analysis of Fig. 10, the following conclusions can be drawn: the territory of the Kashirsky District is subject to dangers from floods, the presence of potentially dangerous hydraulic facilities, wildfires, biological and social dangers; moreover, there are risks of accidents from housing and communal systems and with transport. The risks of property damage are high enough for emergencies within potentially dangerous situations, but, nevertheless, they can occur.

Potentially hazardous facilities with worst type of scenarios are in the zone of acceptable risk of emergency. According to the most probably type of scenarios, the level of regulatory acceptability is exceeded [8].

\section{CONCLUSION}

Recommendations for reducing the risk of emergency So as to minimise the levels of social risk, preventive measures aimed at reducing losses caused by floods must be achieved by:

- bringing hydraulic structures into compliance with safety level requirements of regulatory documents and developing measures to alert populations at a time of threat - which should significantly reduce potential mortality.

clearing riverbeds to increase the flow capacity of flood waters, considering the question of possible dam construction in certain areas and conducting other related engineering activities.

It is advisable to increase the reliability of safety regimes of hazardous facilities and of hydraulic structures operations to minimise the consequences of emergencies. In these cases, procedures should be implemented to accelerate operational services' response time, to improve emergency equipment and to develop warning systems for populations located in areas of potential risk.

In order to reduce the risk of forest fires and mitigate their consequences during the fire hazard period, it is necessary to restrict access to forests and to prepare and equip voluntary units to extinguish forest fires.

Recommendations for reduction of the negative impact of exogenous processes on the Kashirsky Municipal District and its economy through stabilization and protection of vulnerable lands include 2 groups of approaches:

- for gully erosion: embankments and afforestation of developing ravines; planting of bottom plantations for sludge filtration (poplar, willow) in order to reduce bottom erosion; limitation of water-retaining capacity shafts on slopes to reduce soil erosion; meadow formation for side ravines in places of pipeline incision together with strengthening with stones.

- for karst processes: regional planning which involves filling fissures with clay, backfilling of funnels, water-collecting plumbing systems with channels to drain rain and melt water.

In order to prevent the risk of a rise in accidents to life sustaining systems of housing and communal services, scheduled repair compliance, gas system and electricity monitoring and a review of water payment protocols are recommended. This is because any disconnection which arises from malfunction places the life support system and infrastructure at risk.

Based strictly on the objective of reducing potential biological and social emergencies, it is recommended that government departmental emergency monitoring systems be developed whose units will be located in the territories where dangers may occur. Moreover, their equipment, quarantine and observational measures must be improved.

\section{REFERENCES}

1. Ovchinnikova T.V., Kuprienko P.S., Smolyaninov V.M., et al. Shagi resheniya kontseptsii «Bezopasnyi region» [Steps to Solving the Safe Region Concept]. Voronezh, Cifrovaya Poligrafia Publ., 2018, 333 p. (In Russian) 
2. Faleev M.I., ed. Upravlenie riskami tekhnogennykh katastrof i stikhiinykh bedstvii (posobie dlya rukovoditelei organizatsii) [Management of Technogenic Risk and Disasters (Organization Leaders Manual)]. Moscow, 2016, 270 p. (In Russian)

3. Decree of the Government of the Russian Federation dated 17.08.2016 No.806 "On the application of a risk-based approach in the organization of certain types of state control (supervision) and amendments to some acts of the Russian Federation". (In Russian)

4. Order of Rostechnadzor dated 11.04.2016, no. 144, Safety Guide "Methodical bases on conducting hazards analysis and accident risk assessment at hazardous production facilities". (In Russian)

5. GOST R 55059-2012 BChS. Menedzhment riska chrezvychainoi situatsii. Terminy i opredeleniya [GOST R 55059-2012 BCHS. Emergency Risk Management. Terms and Definitions]. Moscow, Standartinform Publ., 2018, 13 p. (In Russian)

6. GOST R 22.10.02-2016 BChS. Menedzhment riska chrezvychainoi situatsii. Dopustimyi risk chrezvychainoi situatsii [GOST R 22.10.02-2016 BCHS. Emergency Risk Management. Acceptable Risk of Emergency]. Moscow, Standartinform Publ., 2019, 18 p. (In Russian)

7. Methodologies for assessing the risks of emergency situations and standards for acceptable risk of emergency situations. Approved by First Deputy Minister of Russian EMERCOM, R.H. Calikov, dated 09.01.2008, No.1-4-60-9. (In Russian)

8. Ragozin A.L., ed. Otsenka i upravlenie prirodnymi riskami. Tematicheskii tom [Assessment and Management of Natural Risks. Thematic Tome]. Moscow, KRUK Publ., 2003, 320 p. (In Russian)

9. Order of Russian EMERCOM dated 08.07.2004, No.329

"On the approval of emergency information criteria" (In Russian)

10. Order of Russian EMERCOM dated 04.11.2004, No.506

"On approval of a standard safety data sheet for a hazardous facility" (reg. by Ministry of Justice of the Russian Federation dated 22.12.2004 No. 6218). (In Russian)

11. Order of Rostechnadzor dated 29.03.2016, No.120 «On approval of the methodology for determining the amount of damage that may be caused to life, health of individuals, property of individuals and legal entities as a result of an accident in a hydraulic structure (except for navigable and port hydraulic engineering structures)". (In Russian) 12. Federal law dated 27.12.2002, No.184-FZ (29.07.2017 edition) "On technical regulating" (In Russian)

13. Federal law dated 22.07.2008, No.123-FZ (29.07.2017 edition) "Technical regulations for fire safety requirements" (In Russian)

\section{AUTHOR CONTRIBUTIONS}

Tatyana V. Ovchinnikova and Nikolay D. Razinkov collected data on natural and technical risks and wrote a manuscript. Pavel S. Kuprienko, Tatyana V. Ashikhmina, Anastasia V. Shmygol and Anastasia A. Pavlenko analyzed the data and calculated the results obtained, participated in writing the manuscript. All authors are equally responsible for plagiarism, self-plagiarism or other ethical transgressions.

\section{БИБЛИОГРАФИЧЕСКИЙ СПИСОК}

1. Овчинникова Т.В., Куприенко П.С., Смольянинов В.М. и др. Шаги решения концепции «Безопасный регион». Воронеж: «Цифровая полиграфия», 2018. 333 с. 2. Управление рисками техногенных катастроф и стихийных бедствий (пособие для руководителей организаций). Под общ. ред. Фалеева М.И. Москва: ФГБУ ВНИИ ГОЧС (ФЦ), 2016. 270 с.

3. Постановление Правительства РФ от 17.08.2016 N 806 «О применении рискориентированного подхода при организации отдельных видов государственного контроля (надзора) и внесения изменений в некоторые акты.

4. Приказ Ростехнадзора от 11.04.2016 N 144 «Об утверждении руководства по безопасности «Методические основы по проведению анализа опасностей и оценки риска аварий на опасных производственных объектах».

5. ГОСТ Р 55059-2012 БчС. Менеджмент риска чрезвычайной ситуации. Термины и определения. М.: Стандартинформ, 2018. 13 с.

6. ГОСТ Р 22.10.02-2016 БЧС. Менеджмент риска чрезвычайной ситуации. Допустимый риск чрезвычайной ситуации. М.: Стандартинформ, 2019. 18 с.

7. Методики оценки рисков чрезвычайных ситуаций и нормативы приемлемого риска чрезвычайных ситуаций. Утв. первым заместителем Министра Российской Федерации по делам гражданской обороны, чрезвычайным ситуациям и ликивдации последствий стихийных бедствий Р.Х. Цаликовым 9.01.2008 N 1-4-60-9. 8. Оценка и управление природными рисками. Тематический том. Под ред. Рагозина А.Л. Москва: «КРУК», 2003. 320 c.

9. Приказ МЧС России от 08.07.2004 N 329 «Об утверждении критериев информации о чрезвычайных ситуациях».

10. Приказ МЧС России от 04.11.2004 N 506 «Об утверждении типового паспорта безопасности опасного объекта» (зарег. в Минюсте РФ 22.12.2004 N 6218). 11. Приказ Ростехнадзора от 29.03.2016 N 120 «Об утверждении Методики определения размера вреда, который может быть причинен жизни, здоровью физических лиц, имуществу физических и юридических лиц в результате аварии гидротехнического сооружения (за исключением судоходных и портовых гидротехнических сооружений)».

12. Федеральный закон от 27.12.2002 N 184-Ф3 (ред. от 29.07.2017) «О техническом регулировании».

13. Федеральный закон от 22.07.2008 N 123-Ф3 (ред. от 29.07.2017) «Технический регламент о требованиях пожарной безопасности».

\section{КРИТЕРИИ АВТОРСТВА}

Татьяна В. Овчинникова и Николай Д. Разиньков собрали данные по природно-техническим рискам, написали рукопись. Павел С. Куприенко, Татьянна В. Ашихмина, Анастасия В. Шмыголь, Анастасия А. Павленко проанализировали данные и проводили расчеты полученных результатов, участвовали в написании рукописи. Все авторы в равной степени несут ответственность при обнаружении плагиата, самоплагиата или других неэтических проблем. 
NO CONFLICT OF INTEREST DECLARATION

The authors declare no conflict of interest.

\section{КОНФЛИКТ ИНТЕРЕСОВ}

Авторы заявляют об отсутствии конфликта интересов.

\section{ORCID}

Татьяна В. Овчинникова / Tatyana V. Ovchinnikova https://orcid.org/0000-0002-7780-1231

Николай Д. Разиньков / Nikolay D. Razinkov https://orcid.org/0000-0001-8637-1029

Павел С. Куприенко / Pavel S. Kuprienko https://orcid.org/0000-0002-7430-8118

Татьяна В. Ашихмина / Tatyana V. Ashikhmina https://orcid.org/0000-0002-2451-2321

Анастасия В. Шмыголь / Anastasia V. Shmygol https://orcid.org/0000-0003-4885-9394

Анастасия А. Павленко / Anastasia A. Pavlenko https://orcid.org/0000-0001-8943-227X 